\title{
PENGARUH METAKOGNISI DAN KEAKTIFAN BELAJAR SISWA TERHADAP HASIL BELAJAR MATEMATIKA
}

\author{
Ayu Arsya Ulichusna ${ }^{1}$, Tri Hariyati Nur Indah Sari ${ }^{2}$, Ganjar Susilo ${ }^{3}$ \\ Universitas Balikpapan $^{1}$, Universitas Balikpapan ${ }^{2}$, Universitas Balikpapan ${ }^{3}$ \\ Pos-el : ayuarsyaulichusna354@gmail.com ${ }^{1}$, tri.hariyati.nis@ uniba-bpn.ac.id ${ }^{2}$, \\ ganjar.susilo@uniba-bpn.ac.id ${ }^{3}$
}

\begin{abstract}
ABSTRAK
Tujuan penelitian ini adalah untuk mengetahui apakah terdapat pengaruh metakognisi dan keaktifan belajar siswa terhadap hasil belajar matematika siswa kelas VIII SMP Negeri 6 Balikpapan Tahun Ajaran 2018/2019 baik secara bersama-sama maupun secara parsial. Populasi dalam penelitian ini adalah siswa kelas VIII SMP Negeri 6 Balikpapan yaitu sebanyak 357, sedangkan sampel dalam penelitian ini yaitu siswa kelas VIII-4 dan VIII-9 sebanyak 73 siswa. Teknik sampling yang digunakan peneliti yaitu menggunakan teknik cluster random sampling. Pendekatan yang digunakan dalam penelitian ini pendekatan kuantitatif dan jenis penelitian adalah kuantitatif asosiatif. Teknik pengumpulan data yang digunakan dalam penelitian ini berupa angket metakognisi, angket keaktifan belajar siswa dan tes hasil belajar matematika. Dalam penelitian ini menggunakan uji $\mathrm{f}$ dan uji $\mathrm{t}$, dan terdapat pengaruh signifikansi pada uji f $0,013<0,05$, pengaruh signifikansi keaktifan belajar siswa pada uji t $0,004<0,05$ dan tidak terdapat pengaruh pada metakognisi $0,270 \geq$ 0,05 .
\end{abstract}

Kata kunci : metakognisi, keaktifan belajar siswa, hasil belajar matematika

\begin{abstract}
The purpose of this study was to determine whether there was a metacognition effect and student learning activity on the mathematics learning outcomes of eighth grade students of SMP Negeri 6 Balikpapan Academic Year 2018/2019 both jointly and partially. The population in this study were as many as 357 grade VIII students of SMP Negeri 6 Balikpapan, while the samples in this study were 73 students of grades VIII-4 and VIII-9. The sampling technique used by researchers is using cluster random sampling technique. The approach used in this research is quantitative approach and the type of research is quantitative asosiative. Data collection techniques used in this study were metacognition questionnaires, student learning activeness questionnaires and mathematics learning outcomes tests. In this study using the f test and t test, and there is a significant effect on the $f$ test $0.013<0.05$, the effect of the significance of student learning activity in the test $0.004<0.05$ and there is no effect on metacognition $0.270 \geq 0.05$.
\end{abstract}

Keywords: metacognition, student learning activity, mathematics learning outcomes 


\section{PENDAhuluan}

Pendidikan merupakan salah satu kebutuhan pokok yang harus dipenuhi oleh manusia. Oleh karena itu pendidikan sangat dibutuhkan untuk perkembangan kognitif, afektif dan psikomotorik manusia. Pada kacamata dunia pendidikan saat ini, siswa memiliki karakter dan tingkah laku di sekolah yang beraneka ragam. Keanekaragaman yang terdapat dalam diri setiap masing-masing siswa memiliki kaitan yang erat pada penerimaan ilmu pengetahuan saat proses pembelajaran di dalam kelas. Ilmu pengetahuan itu sendiri mencakup seluruh aspek pendidikan seperti halnya akar yang kokoh berdiri untuk menegakkan pohon.

Proses pembelajaran yang baik adalah saat siswa mampu menaati peraturan yang diterapkan di sekolah dalam hal belajar dimana siswa diharapkan mampu dan terampil untuk mengikuti dan menerima ilmu pengetahuan yang diberikan oleh guru di kelas. Pada hakikatnya proses pembelajaran yang terarah dan teratur akan berdampak baik. Terarah dalam hal ini, bukan hanya dalam lingkup siswa saja tetapi seluruh warga sekolah yang sadar bahwa segala proses pembelajaran yang teratur itu sangatlah diperlukan.

Proses pembelajaran ini adalah ketika siswa belajar di dalam kelas, dimana siswa saling memiliki tujuan bersekolah yang beraneka ragam. Keanekaragaman siswa dalam bersekolah sangat mempengaruhi pada tingkat pencapaian pada hasil belajar di kelas. Nurmalasari, Winarso, \& Nurhayati (2015, p. 144) menyatakan bahwa hasil belajar siswa sangat dipengaruhi oleh beberapa faktor. Faktor yang mempengaruhi hasil belajar berupa: (1) faktor belajar yang berasal dari luar diri pelajar yaitu lingkungan, instrumental (kurikulum, program, sarana dan guru), (2) faktor yang berasal dari dalam diri pelajar yaitu faktor fisiologis (kondisi fisik secara umum, kondisi panca indra dan faktor psikologis (minat, kecerdasan, bakat, motivasi, dan kemampuan kognitif). Dilihat dari faktor-faktor yang dapat mempengaruhi hasil belajar siswa ini, diharapkan siswa dapat menyadari dan aktif dalam pembelajaran di kelas. Dengan demikian siswa memperoleh perubahan pada hasil belajar khususnya dalam pelajaran matematika.

Dalam hal ini, siswa saat pembelajaran di kelas terdapat masih rendahnya kesadaran siswa bagaimana dia mengelola belajar, keaktifan siswa terlihat masih kurang terutama keaktifan siswa untuk bertanya dan maju ke depan kelas, dan masih rendahnya nilai matematika siswa kelas VIII dilihat dari rata-rata keseluruhan nilai pada saat kelas VII semester 2. Kramarski dan Mizrachi Invalid source specified. mengatakan bahwa pentingnya metakognisi mengarah pada pentingnya hal ini di terapkan pada pembelajaran. Dalam hal ini, peserta didik yang memiliki metakognisi yang baik mampu memperlihatkan keberhasilan akademik yang baik pula dibandingkan dengan peserta didik yang memiliki metakognisi yang kurang baikInvalid source specified..

Anurrahman Invalid source

specified. mengungkapkan bahwa keaktifan siswa dalam belajar merupakan persoalan penting dan mendasar yang harus dipahami, didasari dan dikembangkan oleh setiap guru di dalam proses pembelajaran. Menurut Nurmalasari, Winarso, \& Nurhayati (2015, p. 139) menyatakan bahwa siswa yang mengatakan dirinya tertarik dengan matematika akan secara antusias mengikuti jalannya pembelajaran, tetapi sebaliknya bagi sebagian siswa yang 
kurang tertarik tentu akan menjadi masalah krusial sehingga memunculkan perasaan membosankan ketika pembelajaran berlangsung.

Novianto (2017, p. 2) mengungkapkan bahwa proses pembelajaran bukan lagi sekedar transfer pengetahuan dari guru ke siswa, tetapi merupakan proses pemerolehan konsep yang berorientasi pada keterlibatan siswa secara aktif dan langsung. Ilmu yang telah ditransfer oleh guru sebaiknya ada kesadaran siswa terhadap suatu pengetahuan, dimana dalam melakukannya dengan kesadaran sendiri tanpa ada paksaan dinamakan metakognisi. Chairani (2016, p. 5) mengatakan bahwa metakognisi adalah suatu gambaran bentuk kesadaran seseorang yang terkait dengan kemampuan kognisinya tentang apa yang diketahuinya dan yang tidak diketahuinya berdasarkan pengetahuan yang sudah dimilikinya, pengalaman, proses kognisi dan monitoring dimana ia sendiri terlibat dalam kegiatan kognisinya sendiri. Kramarski dan Mizrachi Invalid source specified. mengatakan bahwa pentingnya metakognisi mengarah pada pentingnya hal ini di terapkan pada pembelajaran. Dalam hal ini, peserta didik yang memiliki metakognisi yang baik mampu memperlihatkan keberhasilan akademik yang baik pula dibandingkan dengan peserta didik yang memiliki metakognisi yang kurang baikInvalid source specified.. Kesadaran siswa diperlukan dengan di lihat dari keaktifan belajar siswa di dalam kelas pada saat pembelajaran sedang berlangsung.

Berdasarkan hasil observasi awal yang peneliti lakukan di SMP Negeri 6 Balikpapan terdapat bahwa masih rendahnya kesadaran siswa bagaimana dia mengelola belajar. Sebagai bukti beberapa siswa masih ada yang ketinggalan membawa buku catatan matematika saat pembelajaran matematika berlangsung. Sehingga siswa kurang memahami saat guru menerangkan di depan kelas, karena siswa tidak ada pegangan buku pelajaran matematika di kelas. Menurut Nurmalasari, Winarso, \& Nurhayati (2015, p. 139) menyatakan bahwa siswa yang mengatakan dirinya tertarik dengan matematika akan secara antusias mengikuti jalannya pembelajaran, tetapi sebaliknya bagi sebagian siswa yang kurang tertarik tentu akan menjadi masalah krusial sehingga memunculkan perasaan membosankan ketika pembelajaran berlangsung.

Selain observasi, peneliti juga melakukan wawancara terhadap guru mata pelajaran matematika kelas VIII. Guru mata pelajaran matematika mengatakan bahwa selama pembelajaran, keaktifan siswa terlihat masih kurang terutama keaktifan siswa untuk bertanya dan maju ke depan kelas. Hal ini dibuktikan pada saat pembelajaran siswa kurang aktif bertanya, dan ketika guru meminta salah satu siswa untuk maju ke depan kelas untuk menjawab soal yang diberikan, tetapi kebanyakan siswa lebih cenderung diam dan beberapa siswa saling menunjuk nunjuk teman lainnya untuk disuruh maju ke depan. Terkadang siswa akan maju ke depan kelas, jika guru yang menunjuk salah satu siswa untuk maju ke depan mengerjakan soal yang berada di papan tulis. Dan masih rendahnya nilai matematika siswa kelas VIII dilihat dari rata-rata keseluruhan nilai pada saat kelas VII semester 2 yaitu di bawah KKM sekolah.

Berdasarkan permasalahan tersebut, maka peneliti tertarik dan termotivasi untuk melakukan penelitian tentang 
pengaruh metakognisi dan keaktifan belajar siswa terhadap hasil belajar matematika siswa kelas VIII SMP Negeri 6 Balikpapan Tahun Ajaran 2018/2019.

\section{METODE PENELITIAN}

Metode penelitian ini adalah kuantitatif asosiatif. Populasi penelitian ini adalah siswa kelas VIII di SMP Negeri 6 Balikpapan Tahun Ajaran 2018/2019 dengan sampel sebanyak 357 siswa. Teknik pengambilan sampel dengan mengguanakan cluster random sampling, variabel penelitian terdiri atas tiga variabel yaitu hasil belajar matematika $(Y)$ sebagai variabel terikat serta metakognisi $\left(X_{1}\right)$ dan keaktifan belajar siswa $\left(X_{2}\right)$ sebagai variabel bebas.

Pengumpulan data dalam penelitian ini adalah: (1) kuesioner (angket) yang dilakukan saat penelitian untuk memperoleh data metakognisi dan keaktifan belajar siswa, (2) Dokumentasi untuk memperoleh dokumentasi kegiatan selama penelitian yaitu berupa foto-foto kegiatan. (3) Tes yang dilakukan saat penelitian untuk memperoleh data hasil belajar matematika siswa kelas VIII di SMP Negeri 6 Balikpapan.

Instrumen metakognisi dan keaktifan belajar siswa yang mengacu pada angket dilakukan uji validitas dan reliabilitas serta hasil tes hasil belajar matematika dilakukan dengan uji validitas, reliabilitas, daya pembeda dan tingkat kesukaran pada soal tes. Analisis data dalam penelitian ini menggunakan analisis regresi linier berganda dengan bantuan SPSS 23.

Berdasarkan perhitungan dari SPSS, dapat dinyatakan pada angket metakognisi ada 17 butir angket yang tidak valid yaitu nomor $2,6,7,8,10,14$, $16,17,20,21,22,23,24,27,33,37$, dan 40. Tetapi ada 23 butir angket yang menunjukkan valid yaitu nomor 1, 3, 4, 5,
$9,11,12,13,15,18,19,25,26,28,29$, $30,31,32,34,35,36,38$, dan 39. Sehingga dapat dikatakan bahwa, peneliti menggunakan 23 butir angket yang valid.

Adapun berdasarkan perhitungan, dapat dinyatakan pada angket keaktifan belajar siswa ada 14 butir angket yang tidak valid yaitu nomor $2,4,13,18,21$, 23,30, 31, 33, 34, 36, 38, 39, dan 40 . Tetapi ada 26 butir angket yang menunjukkan valid yaitu nomor $1,3,5,6$, $7,8,9,10,11,12,14,15,16,17,19,20$, 22, 24, 25, 26, 27, 28, 29, 32, 35, dan 37 . Sehingga dapat dikatakan bahwa, peneliti menggunakan 26 butir angket yang valid.

Selain itu, pada perhitungan validitas tes hasil belajar matematika dilakukan pengambilan keputusan $\mathrm{t}$ hitung $>\mathrm{t}$ tabel sehingga didapatkan hasil soal 1 , soal 4 , soal 5, soal 6 dan soal 8 dikatakan valid sedangkan soal 2 , soal 3 , dan soal 7 dikatakan tidak valid. Sehingga peneliti menetapkan hanya 5 soal yang digunakan untuk penelitian.

Berdasarkan hasil perhitungan reliabilitas pada angket metakognisi diperoleh 0,481 yang menunjukkan kriteria reliabilitas angket tersebut cukup. Adapun dari hasil perhitungan reliabilitas angket keaktifan belajar diperoleh 0,402 yang menunjukkan kriteria reliabilitas angket cukup. Selain itu dari hasil perhitungan reliabilitas hasil belajar matematika, diperoleh 0,725 yang menunjukkan kriteria reliabilitas tes tinggi.

Berdasarkan hasil uji coba instrumen dengan validitas dan reliabilitas maka dapat disimpulkan bahwa angket metakognisi, angket keaktifan belajar dan tes hasil belajar matematika dapat digunakan untuk penelitian. Adapun pada ketiga instrumen ada beberapa item yang harus dihilingkan.

Pada penelitian ini, uji yang digunakan yaitu uji normalitas dengan uji One Sample Kolmogorov Smirnov, uji 
multikolinieritas dengan Variance Inflation Factor (VIF), uji heteroskedastisitas dengan uji Glejser, dan uji linieritas dengan uji F.

Selanjutnya uji regresi ganda digunakan untuk meramalkan (memprediksi) seberapa jauh perubahan nilai variabel terikat bila dua atau lebih variabel bebas dimanipulasi. Dalam hal ini variabel terikat yaitu hasil belajar matematika (Y) dan variabel bebas yaitu kemampuan metakognisi (X1) dan keaktifan belajar (X2). Setelah itu untuk pengujian hipotesis dalam penelitian ini menggunakan uji $\mathrm{F}$ (uji simultan) dan uji $\mathrm{t}$ (uji parsial). Uji $\mathrm{F}$ digunakan untuk menganalisa pengaruh variabel bebas $\mathrm{X} 1$ dan X2 secara bersama-sama (simultan) terhadap variabel terikat (Y). Adapun uji t digunakan untuk mengetahui pengaruh variabel-variabel independen (X1 atau X2) terhadap variabel dependen (Y) secara parsial apakah berpengaruh signifikan atau tidak.

\section{HASIL DAN PEMBAHASAN}

Hasil penelitian yang terdiri dari dua variabel bebas yaitu kemampuan metakognisi dan keaktifan belajar siswa dan satu variabel terikat yaitu hasil belajar matematika dapat dilihat pada Tabel 1.

Tabel 1. Deskripsi Data Hasil Penelitian

\begin{tabular}{|l|c|c|c|c|c|c|}
\hline \multicolumn{1}{|c|}{ Keterangan } & $N$ & Minimum & Maximum & Mean & $\begin{array}{c}\text { Standart } \\
\text { Deviation }\end{array}$ & Variance \\
\hline Metakognisi & 73 & 55 & 78 & 66.59 & 4.76 & 22.33 \\
\hline $\begin{array}{l}\text { Keaktifan Belajar } \\
\text { Siswa }\end{array}$ & 73 & 52 & 75 & 59.37 & 4.69 & 22.01 \\
\hline $\begin{array}{l}\text { Hasil Belajar } \\
\text { Matematika }\end{array}$ & 73 & 36 & 100 & 78.42 & 15.38 & 236.66 \\
\hline
\end{tabular}

Berdasarkan Tabel 1 diketahui bahwa terdapat 73 sampel. Dimana nilai minimum (terendah) pada angket metakognisi adalah 55 dan nilai maximum (tertinggi) adalah 78. Nilai mean (ratarata) yang diperoleh dari keseluruhan nilai data angket metakognisi adalah 66,59. Sedangkan Standard Deviation (standar deviasi) yaitu ukuran penyebaran data dari rata-ratanya dengan nilai sebesar 4,76 dan variance (variansi) yaitu variansi data yang didapat dari kelipatan standar deviasi dengan nilai sebesar 22,33 .

Berdasarkan Tabel 1 dapat diketahui pula nilai minimum (terendah) pada angket keaktifan belajar siswa adalah 52 dan nilai maximum (tertinggi) pada angket keaktifan belajar siswa adalah 75 . Nilai mean (rata-rata) yang diperoleh dari keseluruhan nilai data angket keaktifan belajar siswa adalah 59,37. Sedangkan Standart Deviation (standar deviasi) yaitu ukuran penyebaran data dari rata-ratanya dengan nilai sebesar 4,69 dan variance (variansi) yaitu variansi data yang didapat dari kelipatan standar deviasi dengan nilai sebesar 22,01.

Selain itu berdasarkan Tabel 1 diketahui bahwa nilai minimum (terendah) pada tes hasil belajar matematika siswa adalah 36 dan nilai maximum (tertinggi) pada tes hasil belajar matematika siswa adalah 100. Nilai mean (rata-rata) yang diperoleh dari keseluruhan nilai data tes hasil belajar matematika siswa adalah 78,42. Sedangkan Standart Deviation (standar deviasi) yaitu ukuran penyebaran data dari rata-ratanya dengan nilai sebesar 15,38 dan variance (variansi) yaitu variansi data yang didapat dari kelipatan 
standar deviasi dengan nilai sebesar 236,66.

Hasil uji normalitas penelitian ini diketahui bahwa nilai signifikansi $0,200 \geq$
0,05. Maka dapat disimpulkan bahwa sampel berasal dari populasi yang berdistribusi normal. Adapun hasil uji normalitas dapat dilihat pada Tabel 2.

Tabel 2. Hasil Uji Normalitas

\begin{tabular}{|ll|r|}
\hline \multicolumn{2}{|c|}{ One-Sample Kolmogorov-Smirnov Test } & $\begin{array}{c}\text { Unstandardized } \\
\text { Residual }\end{array}$ \\
\hline$N$ & Mean & 73 \\
Normal Parameters ${ }^{a, b}$ & Std. Deviation & 7.75834308 \\
& Absolute & .000000 \\
Most Extreme Differences & Positive & .056 \\
& Negative & -.085 \\
& & .085 \\
Test Statistic & & $.200^{\mathrm{c}, \mathrm{d}}$ \\
Asymp. Sig. (2-tailed) & &
\end{tabular}

Selain itu berdasarkan hasil uji keaktifan belajar siswa yaitu 1,018 < multikolinearitas diketahui nilai VIF pada $\quad 10,00$ sehingga dapat simpulkan bahwa Tabel 3 diketahui metakognisi dan tidak terjadi multikolinearitas.

Tabel 3. Hasil Uji Multikolinieritas

\begin{tabular}{|c|c|c|c|c|c|c|c|}
\hline \multirow[b]{2}{*}{ Model } & \multicolumn{2}{|c|}{$\begin{array}{c}\text { Unstandardized } \\
\text { Coefficients }\end{array}$} & \multirow{2}{*}{$\begin{array}{c}\text { Standardized } \\
\text { Coefficients }\end{array}$} & \multirow[b]{2}{*}{$t$} & \multirow[b]{2}{*}{ Sig. } & \multicolumn{2}{|c|}{$\begin{array}{c}\text { Collinearity } \\
\text { Statistics }\end{array}$} \\
\hline & $B$ & Std. Error & & & & Tolerance & $V I F$ \\
\hline (Constant) & 57.924 & 16.608 & & 3.488 & .001 & & \\
\hline Metakognisi & 193 & .174 & .126 & 1.113 & .270 & 982 & 1.018 \\
\hline $\begin{array}{l}\text { Keaktifan Belajar } \\
\text { Siswa }\end{array}$ & -.461 & .156 & -.335 & -2.959 & .004 & .982 & 1.018 \\
\hline
\end{tabular}

Berdasarkan hasil uji heteroskedastatis pada Tabel 4 diketahui metakognisi yaitu $0,581>0,05$ maka dapat disimpulkan bahwa tidak terjadi heterokedastatis. Sedangkan hasil uji heteroskedastatis pada keaktifan belajar siswa yaitu 0,249>
0,05 maka dapat disimpulkan bahwa tidak terjadi heterokedastatis. Sehingga dapat disimpulkan bahwa tidak terjadi heteroskedastatis pada masing-masing variabel bebas.

Tabel 4

Hasil Uji Heteroskedastatis

\begin{tabular}{|c|c|c|c|c|c|}
\hline \multirow[b]{2}{*}{ Model } & \multicolumn{2}{|c|}{$\begin{array}{c}\text { Unstandardized } \\
\text { Coefficients }\end{array}$} & \multirow{2}{*}{$\begin{array}{c}\begin{array}{c}\text { Standardized } \\
\text { Coefficients }\end{array} \\
\text { Beta } \\
\end{array}$} & \multirow[b]{2}{*}{$T$} & \multirow[b]{2}{*}{ Sig. } \\
\hline & $B$ & Std. Error & & & \\
\hline (Constant) & 2.587 & 9.305 & & .278 & .782 \\
\hline Metakognisi & $-.05 \mathrm{a}$ & .097 & -.066 & -.554 & .581 \\
\hline $\begin{array}{l}\text { Keaktifan Belajar } \\
\text { Siswa }\end{array}$ & .102 & .087 & .139 & 1.163 & .249 \\
\hline
\end{tabular}


Berdasarkan hasil uji linieritas pada Tabel 5 diketahui signifikansi sebesar

$0,902 \geq 0,05$ sehingga terdapat hubungan linier metakognisi terhadap hasil belajar matematika.

Tabel 5. Hasil Uji Linieritas Metakognisi Terhadap Hasil Belajar Matematika

\begin{tabular}{|c|c|c|c|c|c|c|c|}
\hline & & & $\begin{array}{l}\text { Sum of } \\
\text { Squares }\end{array}$ & $D f$ & $\begin{array}{l}\text { Mean } \\
\text { Square }\end{array}$ & $F$ & Sig. \\
\hline \multirow{5}{*}{$\begin{array}{l}\text { Hasil Belajar } \\
\text { Matematika * } \\
\text { Metakognisi }\end{array}$} & Between & (Combined) & 3494.090 & 22 & 158.822 & .586 & .914 \\
\hline & Groups & Linearity & 105.450 & 1 & 105.450 & .389 & .536 \\
\hline & & $\begin{array}{l}\text { Deviation from } \\
\text { Linearity }\end{array}$ & 3388.639 & 21 & 161.364 & .596 & .902 \\
\hline & \multicolumn{2}{|c|}{ Within Groups } & 13545.746 & 50 & 270.915 & & \\
\hline & \multicolumn{2}{|l|}{ Total } & 17039.836 & 72 & & & \\
\hline
\end{tabular}

Adapun berdasarkan hasil uji linearitas pada Tabel 6 diketahui signifikansi sebesar $0,067 \geq 0,05$ sehingga terdapat

hubungan linier keaktifan belajar siswa terhadap hasil belajar matematika.

Tabel 6. Hasil Uji Linieritas Keaktifan Belajar Terhadap Hasil Belajar Matematika

\begin{tabular}{|c|c|c|c|c|c|c|c|}
\hline & & & $\begin{array}{l}\text { Sum of } \\
\text { Squares }\end{array}$ & $D f$ & $\begin{array}{l}\text { Mean } \\
\text { Square }\end{array}$ & $F$ & Sig. \\
\hline \multirow{5}{*}{$\begin{array}{l}\text { Hasil Belajar } \\
\text { Matematika * } \\
\text { Keaktifan Belajar } \\
\text { Siswa }\end{array}$} & \multirow{3}{*}{$\begin{array}{l}\text { Between } \\
\text { Groups }\end{array}$} & (Combined) & 8268.852 & 19 & 435.203 & 2.630 & .070 \\
\hline & & Linearity & 1887.083 & 1 & 1887.083 & $\begin{array}{c}11.40 \\
3\end{array}$ & .045 \\
\hline & & $\begin{array}{l}\text { Deviation from } \\
\text { Linearity }\end{array}$ & 6381.770 & 18 & 354.543 & 2.142 & .067 \\
\hline & \multicolumn{2}{|c|}{ Within Groups } & 8770.983 & 53 & 165.490 & & \\
\hline & \multicolumn{2}{|l|}{ Total } & 17039.836 & 72 & & & \\
\hline
\end{tabular}

Berdasarkan hasil uji $\mathrm{F}$ pada Tabel 7 diketahui nilai $\mathrm{F}$ yaitu $0,013<0,05$ sehingga terdapat pengaruh secara bersama-sama antara metakognisi dan keaktifan belajar siswa terhadap hasil belajar matematika.

Tabel 7. Hasil Uji F

\begin{tabular}{|l|c|c|c|c|c|}
\hline \multicolumn{1}{|c|}{ Model } & Sum of Squares & Df & Mean Square & $F$ & Sig. \\
\hline Regression & 574.842 & 2 & 287.421 & 4.642 & $.013^{\mathrm{b}}$ \\
Residual & 4333.816 & 70 & 61.912 & & \\
Total & 4908.658 & 72 & & & \\
\hline
\end{tabular}

Berdasarkan hasil uji t pada Tabel 8 diketahui variabel $X_{1}$ yaitu $0,270 \geq 0,05$ maka $\mathrm{H}_{0}$ diterima, sehingga tidak terdapat pengaruh metakognsi terhadap hasil belajar matematika. Sedangkan hasil uji t variabel $X_{2}$ yaitu $0,004<0,05$ maka $\mathrm{H}_{0}$ ditolak, sehingga terdapat pengaruh keaktifan belajar siswa terhadap hasil belajar matematika. 
Tabel 8. Hasil Output Uji t

\begin{tabular}{|c|c|c|c|c|c|}
\hline \multirow{2}{*}{ Model } & \multicolumn{3}{|c|}{$\begin{array}{c}\text { Standardized } \\
\text { Coefficients }\end{array}$} & & \\
\cline { 2 - 4 } & $B$ & Std. Error & Beta & $t$ & Sig. \\
\hline (Constant) & 57.924 & 16.608 & & 3.488 & .001 \\
Metakognisi & .193 & .174 & .126 & 1.113 & .270 \\
Keaktifan & -.461 & .156 & -.335 & -2.959 & .004 \\
Belajar Siswa & & & & & \\
\hline
\end{tabular}

Sebagai hasil penelitian, setelah dilakukan analisa data dengan menggunakan metode statistik. Maka dapat dibahas pada penelitian ini untuk menjawab hipotesis, uji hipotesis digunakan untuk mengetahui prediksi penelitian. Dimana untuk menjawab hipotesis dalam penelitian ini, menggunakan analisis regresi berganda. Dari data yang telah diperoleh maka hasil analisis dengan menggunakan batuan program SPSS 23 dengan uji diperoleh hasil uji $F$ yaitu $0,013<0,05$ dengan taraf signifikansi $\alpha=0,05$. Sehingga dapat disimpulkan bahwa hipotesis pertama terjawab yaitu terdapat pengaruh metakognisi dan keaktifan belajar siswa secara bersama-sama terhadap hasil belajar matematika siswa kelas VIII SMP Negeri 6 Balikpapan Tahun Ajaran 2018/2019. Hal ini didukung oleh Fajriani \& Nurdahniar (2016, p. 289) yang menyatakan bahwa jika aktivitas kognisi seseorang seperti perencanaan, monitoring, dan mengevaluasi penyelesaian suatu tugas tertentu merupakan metakognisi secara alami. Dalam hal ini, guru tidak hanya memperhatikan hasil belajar siswa saja tetapi juga memperhatikan faktor-faktor yang mempengaruhi proses dan hasil belajar matematika siswa tersebut.

Berdasarkan data yang telah diperoleh maka hasil analisis dengan menggunakan batuan program SPSS 23 dengan uji $\mathrm{t}$ pada variabel metakognisi yaitu $0,270 \geq 0,05$. Sehingga dapat disimpulkan bahwa hipotesis kedua terjawab yaitu tidak terdapat pengaruh metakognisi terhadap hasil belajar matematika siswa kelas VIII SMP Negeri 6 Balikpapan Tahun Ajaran 2018/2019. Dilihat dari penelitian Nurmalasari, Winarso, \& Nurhayati (2015, p. 141-144) menyatakan bahwa kontribusi kemampuan metakognisi terhadap hasil belajar $R$ Square yaitu 28,9 \% dan 71,1 \% dipengaruhi faktor lain. Faktor yang mempengaruhi hasil belajar berupa: (1) faktor belajar yang berasal dari luar diri pelajar yaitu lingkungan, instrumental (kurikulum, program, sarana dan guru), (2) faktor yang berasal dari dalam diri pelajar yaitu faktor fisiologis (kondisi fisik secara umum, kondisi panca indra dan faktor psikologis (minat, kecerdasan, bakat, motivasi, dan kemampuan kognitif). Mengatakan bahwa ada faktorfaktor lain yang mempengaruhi sehingga metakognisi tidak terdapat berpengaruh terhadap hasil belajar.

Berdasarkan data yang telah diperoleh maka hasil analisis dengan menggunakan batuan program SPSS 23 dengan uji $t$ pada variabel keaktifan belajar siswa yaitu $0,004<0,05$ maka $\mathrm{H}_{0}$ ditolak. Sehingga dapat disimpulkan bahwa hipotesis ketiga terjawab yaitu terdapat pengaruh keaktifan belajar siswa terhadap hasil belajar matematika siswa kelas VIII SMP Negeri 6 Balikpapan Tahun Ajaran 2018/2019. Susanti, Darminto, \& Yuzianah (2013, p. 128) mengatakan bahwa keaktifan belajar 
seorang siswa dapat terlihat dari hasil belajarnya. Dipertegas oleh Nurmalasari, Winarso, \& Nurhayati (2015, p. 139) mengatakan bahwa faktor internal mempunyai pengaruh yang sangat besar terhadap hasil belajar yang dicapai siswa, $70 \%$ hasil belajar siswa di sekolah dipengaruhi oleh kemampuan siswa dan $30 \%$ dipengaruhi oleh lingkungan. Ramlah, Firmansyah, \& Zubair (2014, p. 75) menyatakan bahwa terdapat perbedaan yang signifikan nilai prestasi belajar matematika siswa yang memiliki keaktifan tinggi dan siswa yang memiliki prestasi belajar yang tinggi dibandingkan dengan siswa yang memiliki keaktifan rendah.

\section{KESIMUPLAN}

Berdasarkan hasil penelitian dan pembahasan dapat disimpulkan bahwa hipotesis pertama terjawab bahwa terdapat pengaruh secara bersama-sama antara metakognisi dan keaktifan belajar siswa terhadap hasil belajar matematika siswa kelas VIII SMP Negeri 6 Balikpapan Tahun Ajaran 2018/2019. Berdasarkan hasil uji F yaitu 0,013 <0,05 dengan taraf signifikansi $\alpha=0,05$.

Hipotesis kedua terjawab bahwa tidak terdapat pengaruh metakognisi terhadap hasil belajar matematika siswa kelas VIII SMP Negeri 6 Balikpapan Tahun Ajaran 2018/2019 dilihat dari variabel $X_{1}$ pada uji t yaitu $0,270 \geq 0,05$. Dan Hipotesis ketiga terjawab bahwa terdapat pengaruh keaktifan belajar siswa terhadap hasil belajar matematika siswa kelas VIII SMP Negeri 6 Balikpapan Tahun Ajaran 2018/2019 dilihat pada variabel $X_{2}$ pada uji t yaitu $0,004<0,05$.

\section{DAFTAR PUSTAKA}

Chairani, Z. (2016). Metakognisi Siswa dalam Pemecahan Masalah
Matematika. Yogyakarta: CV. Budi Utama.

Fajriani, \& Nurdahniar. (2016). Pengaruh Metakognisi Terhadap Hasil Belajar Matematika Siswa Kelas X SMA Negeri Se Kabupaten Bulukumba. Prosiding Seminar Nasional, Volume II Nomor 1, 285-290.

Novianto, A. (2017). Peningkatan Hasil Belajar Siswa SMP Negeri 3 Pule Trenggalek Dengan Strategi Broup Investigation. Jurnal Program Studi Pendidikan Matematika, Volume III Nomor 2, 1-15.

Nurmalasari, L. R., Winarso, W., \& Nurhayati, E. (2015). Pengaruh Kemampuan Metakognisi terhadap Hasil Belajar Matematika di SMP Negeri 2 Leuwimunding Kabupaten Majalengka. Nusantara of Research, 144.

Ramlah, Firmansyah, D., \& Zubair, H. (2014). Pengaruh Gaya Belajar dan Keaktifan Siswa Terhadap Prestasi Belajar Matematika (Survey Pada SMP Negeri di Kecamatan Klari Kabupaten Karawang). Jurnal Ilmiah Solusi, Volume I Nomor 3, 68-75.

Susanti, E. A., Syafmen, W., \& Ramalisa, Y. (2011). Studi Perbandingan Hasil Belajar Matematika Siswa Dengan Menggunakan odel Pembelajaran Kooperatif Tipe The Learning Cell Dan Tipe Artikulasi Di Kelas VII SMPN 7 MA. JAMBI. Edumatica, Volume I Nomor 2, 4959. 